\title{
Cultured Human Endothelial Cells Stimulated with Cytokines or Endotoxin Produce an Inhibitor of Leukocyte Adhesion
}

\author{
M. E. Wheeler, F. W. Luscinskas, M. P. Bevilacqua, and M. A. Gimbrone, Jr. \\ Vascular Research Division, Department of Pathology, Brigham and Women's Hospital and Harvard Medical School, \\ Boston, Massachusetts 02115
}

\begin{abstract}
Activation of cultured human endothelial cells (HEC) by inflammatory stimuli, such as interleukin 1 (IL-1), tumor necrosis factor (TNF), and bacterial endotoxin (lipopolysaccharide, LPS), increases their surface adhesiveness for blood leukocytes and related cell lines. We now report that activated HEC also generate a soluble leukocyte adhesion inhibitor (LAI), which accumulates in conditioned media from IL-1-, TNF-, or LPS-treated, but not sham-treated, HEC cultures. LAI significantly inhibits the adhesion of PMN and monocytes to activated, but not unactivated, HEC. In contrast, LAI has no effect on the adhesion of lymphocytes, the promyelocytic cell line HL-60 or the monocyte-like cell line U937 to HEC monolayers. LAI appears to act directly on the leukocyte, but does not inhibit either agonist-induced responses in PMN (membrane depolarization, changes in cytosolic calcium concentration, superoxide production) or PMN attachment to serumcoated plastic surfaces. Endothelial generation of LAI is blocked by actinomycin $D$ but not by aspirin or indomethacin. Preliminary biochemical characterization indicates that LAI is a soluble, protein-containing molecule that is heat- and acidstable. Fractionation by HPLC gel filtration yields a single peak of LAI activity $\left(14,000<M_{r}>24,000\right)$. Thus, in addition to proadhesive cell surface changes, the endothelium may also actively contribute to the regulation of endothelial-leukocyte interactions at sites of inflammation in vivo through the production of soluble adhesion inhibitors such as LAI.
\end{abstract}

\section{Introduction}

Recent studies by our laboratory and others have demonstrated that certain inflammatory cytokines, such as interleukin 1 (IL-1), tumor necrosis factor (TNF), ${ }^{1}$ as well as gram

Presented in part at the Annual Meeting of the Federation of American Societies for Experimental Biology, Washington, DC, April 1987, and published in abstract form (1987. Fed. Proc. 46:758).

Address reprint requests to Dr. Wheeler, Department of Pathology, Brigham and Women's Hospital, 75 Francis Street, Boston, MA 02115. 1988.

Received for publication 12 June 1987 and in revised form 18 April

1. Abbreviations used in this paper: CM, conditioned media; ELAM-1, endothelial-leukocyte adhesion molecule-1; GM-CSF, granulocyte-monocyte colony stimulating factor; HEC, human umbilical vein endothelial cell(s); hmIL-1, human monocyte-derived interleukin 1; LAI, leukocyte adhesion inhibitor; LPS, gram negative bacterial endotoxin; rIL-1 $(\alpha, \beta)$, recombinant IL-1; rTNF, recombinant tumor necrosis factor; TIS, transferrin/insulin/selenium.

J. Clin. Invest.

(C) The American Society for Clinical Investigation, Inc. $0021-9738 / 88 / 10 / 1211 / 08 \$ 2.00$

Volume 82, October 1988, 1211-1218 negative bacterial endotoxin (lipopolysaccharide, LPS), can act directly on cultured human endothelial cells to increase the adhesiveness of their surfaces for human blood leukocytes and the related leukocyte cell lines HL-60 and U937 (1-8). Further, we have shown that this increased endothelial adhesiveness for PMN and HL-60 cells can be attributed, in part, to expression of a newly synthesized cell surface structure we have designated endothelial-leukocyte adhesion molecule-1 (ELAM-1) (9).

While investigating the potential contributions of soluble products released by the cytokine-activated endothelial cell to this adhesive interaction, we became aware of a potent inhibitor of leukocyte adhesion. We now report that cultured human endothelial cells treated with IL-1, TNF, or LPS, produce a soluble, noncyclooxygenase-dependent inhibitor that acts selectively on PMN and monocytes, but not lymphocytes, to block their adhesion to the "hyperadhesive" endothelial surface. The action of this endothelial-derived leukocyte adhesion inhibitor (LAI) appears to be directed towards the leukocyte; however, it does not produce a global inhibition of leukocyte responsiveness to soluble inflammatory stimuli, such as the chemotactic peptide, FMLP, leukotriene $\mathrm{B}_{4}\left(\mathrm{LTB}_{4}\right)$, and phorbol 12-myristate 13-acetate (PMA). LAI may play a role in the modulation of leukocyte-vessel wall interactions at sites of inflammation in vivo.

\section{Methods}

Cell cultures. Human umbilical vein endothelial cells were isolated from two to five cord segments, pooled and grown in primary culture using medium 199 (M199; M.A. Bioproducts, Bethesda, MD) with $20 \%$ fetal calf serum (FCS; Gibco Laboratories, Grand Island, NY) and antibiotics as previously described (1). Several strains were serially passaged (1:3 split ratios) using M199-20\% FCS supplemented with endothelial cell growth factor $(50-100 \mu \mathrm{g} / \mathrm{ml}$; Biomedical Technologies, Inc., Stoughton, MA) and porcine intestinal heparin (50-100 $\mu \mathrm{g} / \mathrm{ml}$; Sigma Chemical Co., St. Louis, MO) in tissue culture flasks (75 $\mathrm{cm}^{2}$, Costar Data Packaging Corp., Cambridge, MA) coated with $0.1 \%$ gelatin (Bactogelatin 0143-02; Difco Laboratories, Detroit, MI). For experimental use, HEC strains were plated (passage levels 2-5) on 15-mm Thermanox plastic coverslips (Miles Scientific, Naperville, IL) in Costar 24 wells, in 96 well microtiter wells (Costar Data Packaging Corp.), or 100-mm tissue culture dishes (Corning Glass Works, Corning, NY) coated with either fibronectin $\left(1 \mu \mathrm{g} / \mathrm{cm}^{2}\right.$; Meloy Laboratories, Springfield, VA) or $0.1 \%$ gelatin.

Isolation and radiolabeling of leukocytes. Blood was drawn from normal human volunteers into CCD buffer $(1: 9 ; 100 \mathrm{mM}$ sodium citrate, $130 \mathrm{mM}$ glucose, $\mathrm{pH}$ 6.5). Suspensions of PMN (> 95\%) were prepared as previously described (1). Mononuclear leukocytes were isolated on lymphocyte separation media (Litton Bionetics, Inc., Charleston, SC) and further fractionated into either a monocyteenriched population (75-88\%) according to the method of Recalde (10) or lymphocyte suspensions ( $>95 \%$ ) by monocyte depletion on serum-coated plastic petri dishes. The promyelocytic cell line HL-60 and the monocyte-like cell line U937 were cultured as described (1). Each leukocyte type was radiolabeled with " Corp., Arlington Heights, IL) (1). 
Inflammatory mediators and biochemical reagents. The following reagents were obtained from the sources indicated. Human monocyte derived IL-1 (hmIL-1), human recombinant IL-1- $\beta$ (rIL-1 $\beta$ ), and human recombinant granulocyte-monocyte colony stimulating factor (GM-CSF): Genzyme, Inc., Boston, MA; human recombinant IL-1- $\alpha$ (rIL-1 $\alpha$ ) expressed in E. coli: Cistron Technology, Pine Brook, NJ; human recombinant TNF (rTNF), human rIL-2 and human rIL-1 $\beta$ were a gift from Biogen Inc. (Cambridge, MA); gram negative bacterial endotoxin ( $E$. coli 0111:B4): Difco Laboratories; affinity purified human interferon gamma ( $\gamma$-IFN): Interferon Sciences, Inc., New Brunswick, NJ; trypsin (type XI), thrombin (from bovine plasma, T6634), FMLP, PMA, gelatin-agarose, and ammonium sulphate (grade III): Sigma Chemical Co.; LTB $_{4}$ : Biomol, Inc., Philadelphia, PA; diS- $\mathrm{C}_{3}-(5)$ and Fura-2/AM: Molecular Probes, Eugene, OR; concanavalin A-agarose: Vector Laboratories, Burlingame, CA; heparinSepharose CL-6B, and pepsin-agarose: Pharmacia, Uppsala, Sweden. Heparinase from Flavobacterium heparinium was kindly provided by Dr. Howard Bernstein (Massachusetts Institute of Technology, Cambridge, MA).

Generation of LAI activity. To prepare IL-1 conditioned medium (IL-1 CM) or sham conditioned medium (SHAM CM), confluent HEC monolayers (100 mm dishes) were incubated with or without IL-1 (2.5-5 U/ml hmIL- 1 or rIL- $\beta$ ) in RPMI 1640 which contains $0.5 \mathrm{mM}$ $\mathrm{Ca}^{2+}$ and $0.5 \mathrm{mM} \mathrm{Mg}^{2+}$ (RPMI; M.A. Bioproducts, Walkersville, MD), supplemented with the following: $(a)$ no additional protein, $(b)$ a defined nonserum additive containing $5 \mu \mathrm{g} / \mathrm{ml}$ transferrin, $5 \mu \mathrm{g} / \mathrm{ml}$ insulin, and $5 \mathrm{ng} / \mathrm{ml}$ selenium (final concentrations) (TIS; Collaborative Research, Cambridge, MA), (c) $1 \%$ (vol/vol) fetal calf serum (FCS, endotoxin $<0.027 \mathrm{ng} / \mathrm{ml}$, Hyclone Laboratories Inc., Logan, UT), (d) $10 \mathrm{mg} / \mathrm{ml}$ bovine serum albumin (BSA, Fraction V; Sigma Chemical Co.). After $4 \mathrm{~h}$, all dishes were washed with $5 \mathrm{ml}$ Hanks' balanced salt solution (HBSS; M.A. Bioproducts) without $\mathrm{Ca}^{2+}$ or $\mathrm{Mg}^{2+}$ to remove the cytokine-containing medium and incubated for an additional $5 \mathrm{~h}$ in RPMI alone or supplemented with TIS, FCS, or BSA. Media were collected, centrifuged $(400 \mathrm{~g}, 10 \mathrm{~min})$ and usually frozen at $-80^{\circ} \mathrm{C}$.

In certain experiments, actinomycin D $(5 \mu \mathrm{g} / \mathrm{ml}$, Sigma Chemical Co.), acetylsalicylic acid (500 $\mu \mathrm{M}$; Fisher Scientific Co., Pittsburgh, PA), or indomethacin ( $5 \mu \mathrm{M}$; Sigma Chemical Co.) were added to the endothelial cultures $30 \mathrm{~min}$ before the addition of rIL-1 $\beta$ and allowed to remain in the medium throughout the pretreatment phase. After treatment with these inhibitors, both cytokine-activated and unactivated HEC monolayers remained intact by phase contrast microscopy and were $96-98 \%$ viable by trypan blue exclusion. Under these experimental conditions, actinomycin D blocks the expression of new surface proteins in cytokine-stimulated human endothelial cells (9). The efficacy of treatment with the cyclooxygenase inhibitors was determined by radioimmunoassay of 6-keto- PGF $_{1 \alpha}$ production in cytokine-activated and unactivated HEC with and without addition of calcium ionophore (courtesy of Dr. A. Schafer, Brigham and Womens' Hospital, Boston, MA).

Assay of LAI activity. LAI activity was assayed using a modification of our previously described leukocyte-endothelial monolayer adhesion assay (9). In brief, target monolayers, consisting of confluent HEC grown on Thermanox coverslips or in microtiter wells, were pretreated in RPMI supplemented with FCS, BSA, or TIS with and without hmIL-1 or rIL-1 $\beta(2.5-5 \mathrm{U} / \mathrm{ml}, 4 \mathrm{~h})$. Aliquots of ${ }^{111}$ In-labeled leukocyte suspensions $\left(2 \times 10^{7}\right.$ cells $/ \mathrm{ml}$ in RPMI with the appropriate supplement) were diluted 1:10 in IL-1 CM, SHAM CM, or fresh medium (final concentration: $2 \times 10^{6} \mathrm{cells} / \mathrm{ml}$ ), added to washed monolayers, and incubated at $37^{\circ} \mathrm{C}$ for $10 \mathrm{~min}$ under static conditions. The adhesion assay was terminated by a standardized wash procedure for Thermanox coverslips (1), or by centrifugation $(350 \mathrm{~g}, 5 \mathrm{~min})$ in the case of microtiter plates $(9,11)$. The number of adherent ${ }^{111}$ In-labeled leukocytes was determined from the monolayer bound radioactivity and the specific activity (counts per minute per cell) of the leukocyte preparation using a gamma 5500 counter (Beckman Instruments, Inc., Fullerton, CA). LAI activity, expressed as percent inhibition of leukocyte adhesion, was calculated as: 1 - No. cells adherent $/ \mathrm{mm}^{2}$ in IL-1
$\mathrm{CM} /$ No. cells adherent $/ \mathrm{mm}^{2}$ in SHAM CM $\times 100$, and expressed as mean \pm SEM. Significance was tested with a two-tailed Student's $t$ test.

To test adhesion to serum-coated plastic surfaces, $50 \mu \mathrm{l}$ of $50 \%$ fresh human serum, $50 \%$ decomplemented $\left(56^{\circ} \mathrm{C}, 30 \mathrm{~min}\right)$ human serum, or $50 \%$ zymosan activated human serum was added to microtiter plates and incubated at $37^{\circ} \mathrm{C}$ for $1-2 \mathrm{~h}$. The wells were washed with HBSS minus immediately before the addition of radiolabeled PMN and further incubated for $30 \mathrm{~min}$ at $37^{\circ} \mathrm{C}$. The number of adherent leukocytes per square millimeter of plastic surface was determined as described above.

Assays of PMN activation. PMN responsiveness to soluble stimuli $\left(10^{-7} \mathrm{M}\right.$ FMLP, $10^{-7} \mathrm{M} \mathrm{LTB}_{4}, 100 \mathrm{ng} / \mathrm{ml}$ PMA) was assessed by quantitative measurement of changes in membrane potential and cytosolic free calcium concentrations. Changes in membrane potential were evaluated with the fluorescent cyanine probe diS- $\mathrm{C}_{3}-(5)$ as previously described $(12,13)$ using a SPEX (Edison, NJ) Fluorolog II (model CM-1) spectrofluorimeter with the cuvette compartment controlled at $37^{\circ} \mathrm{C}$ and equipped for continuous stirring of cell suspensions. For measurement of $\mathrm{Ca}^{2+}$-sensitive Fura-2 fluorescence, suspensions of PMN $\left(10^{7}\right.$ cells $\left./ \mathrm{ml}\right)$ were resuspended in $\mathrm{HBSS}$ without $\mathrm{Ca}^{2+}$ and $\mathrm{Mg}^{2+}$ and incubated with Fura-2/AM (stock solution, $1 \mathrm{mM}$ in dimethylsulfoxide), at a final concentration of $1 \mu \mathrm{M}$, for $10 \mathrm{~min}$ at $37^{\circ} \mathrm{C}$. The cells were diluted 5-fold with HBSS with $0.5 \%$ BSA and further incubated for $15 \mathrm{~min}$ at $37^{\circ} \mathrm{C}$. The cells were washed twice by centrifugation with cold HBSS with $0.1 \%$ BSA and stored at $10^{\circ} \mathrm{C}$. Immediately before assay, cells were pelleted in a Beckman Microfuge (model B), resuspended in $1.9 \mathrm{ml}$ of warm HBSS plus $\mathrm{Ca}^{2+}$ and $\mathrm{Mg}^{2+}$, and allowed to equilibrate in a cuvette for $5 \mathrm{~min}$ before addition of agonists. Fluorescence measurements were made in a SPEX Fluorolog II spectrofluorimeter equipped with a beam splitter, two excitation monochromaters, and a dual mirror chopping mechanism in a specialized optical configuration to allow rapid alternating $(30 \mathrm{~Hz})$ excitation of Fura- 2 at two wavelengths, 340 and $380 \mathrm{~nm}$. Excitation band widths were set at $6.6 \mathrm{~nm}$. The ratio of the emitted fluorescence signals (505 $\mathrm{nm}, 7.2 \mathrm{~nm}$ ) permits the calculation of intracellular $\mathrm{Ca}^{2+}$ concentration, which is independent of cell number, dye loading, and dye bleaching. Fluorescence signals were calibrated using $80 \mu \mathrm{M}$ digitonin to permit equilibration of intracellular and extracellular $\mathrm{Ca}^{2+}$ (fluorescence maximum) followed by the addition of $100 \mathrm{mM}$ Tris, $300 \mathrm{mM}$ EGTA, pH > 10.0 (fluorescence minimum). The basal and maximum increase in intracellular $\mathrm{Ca}^{2+}$ were calculated as described by Grynkiewicz et al. (14). Superoxide generation was determined using cytochrome $c$ reduction assay as described by Cohen et al. (15).

Enzymatic treatments of LAI. SHAM CM and IL-1 CM collected in RPMI plus TIS were filtered through an Amicon YM 30 membrane (nominal molecular weight cut-off 30,000; Amicon Corp., Danvers, MA) under $\mathrm{N}_{2}$ and treated with trypsin $\left(1000 \mathrm{U} / \mathrm{ml}, \mathrm{pH} 7,37^{\circ} \mathrm{C}, 18 \mathrm{~h}\right)$, thrombin $\left(2 \mathrm{U} / \mathrm{ml}, 37^{\circ} \mathrm{C}, 2 \mathrm{~h}\right)$, heparinase $\left(15 \mathrm{U} / \mathrm{ml}, 30^{\circ} \mathrm{C}, 2 \mathrm{~h}\right)$, or pepsin-linked agarose $\left(4,500 \mathrm{U} / \mathrm{ml}, \mathrm{pH} 4,18 \mathrm{~h}, 37^{\circ} \mathrm{C}\right)$. Enzyme treatments were stopped by boiling $\left(15 \mathrm{~min}, 100^{\circ} \mathrm{C}\right)$ or, in the case of pepsin-linked agarose, by centrifugation in a Beckman microfuge and removal of the agarose beads. Trypsin and thrombin retained full activity in both SHAM CM and IL-1 CM as determined by the hydrolysis of BAEE ( $N \alpha$-benzoyl-L-arginine ethyl ester; Sigma Chemical Co.) in a spectrophotometric assay and plasma clotting activity, respectively.

HPLC. HPLC was performed with a Waters Associates (Milford, MA) liquid chromatography system composed of two model 510 solvent pumps and a programmable Systems Controller gradient maker. Column effluent was monitored at $280 \mathrm{~nm}$ with a Waters model 481 absorbance detector. IL-1 CM and SHAM CM in RPMI plus TIS were filtered on an Amicon YM 30 membrane, the effluent concentrated 20-40 times on a YM 5 membrane (nominal molecular weight cut-off 5,000 ), dialyzed against distilled $\mathrm{H}_{2} \mathrm{O}$ (Spectrapor 7, 10,000 molecular weight cutoff, Spectrum Medical Industries, Los Angeles, CA), and lyophilized. Lyophilized samples were reconstituted in $0.2 \mathrm{M}$ acetic acid, $0.1 \mathrm{M}$ triethylamine ( $\mathrm{pH} 3.9$ ) at a concentration of $\sim 1 \mathrm{mg} / \mathrm{ml}$ and applied (250- $\mu$ l sample) to a Waters Protein-PAK 125 gel filtration 
column $(7.8 \mathrm{~mm} \times 30 \mathrm{~cm})$. The column was run as an isochratic system at a flow rate of $1.8 \mathrm{ml} / \mathrm{min}$ and $0.9-\mathrm{ml}$ fractions were collected. Fractions were dialyzed $18 \mathrm{~h}\left(4^{\circ} \mathrm{C}\right)$ against PBS $(136 \mathrm{mM} \mathrm{NaCl}, 0.3$ $\mathrm{mM} \mathrm{KCl}, 0.8 \mathrm{mM} \mathrm{Na}_{2} \mathrm{HPO}_{4}, 0.1 \mathrm{mM} \mathrm{KH_{2 }} \mathrm{PO}_{4}, \mathrm{pH}$ 7.4). Fractions were diluted into RPMI plus FCS and assayed in a standard monolayer adhesion assay. Protein determinations were performed using Bio-Rad protein reagent (Bio-Rad Laboratories, Richmond, CA).

\section{Results}

As illustrated in Fig. 1, treatment of HEC monolayers with hmIL-1 results in a time-dependent increase in surface adhesiveness for polymorphonuclear leukocytes, as we have previously reported (1). In our standard monolayer adhesion assays, the cytokine-containing medium routinely was aspirated and each well washed with fresh medium immediately before the addition of radiolabeled leukocytes. In this "washed" system, PMN adhesion to IL-1 treated HEC monolayers was significantly increased with respect to untreated monolayers as early as $1 \mathrm{~h}$ post-IL-1, with peak adhesion occurring between 3 and $4 \mathrm{~h}$, followed by a gradual decline. In contrast, when the pretreatment media was not removed and PMN were added directly to the well (unwashed system), markedly less PMN adhesion was observed especially after $3 \mathrm{~h}$. PMN adhesion to untreated HEC monolayers was the same for both washed and unwashed conditions at all time points examined. Based on these observations, we hypothesized that the conditioned media from IL-1-treated, but not untreated, HEC monolayers contained an activity that inhibits leukocyte-endothelial adhesion (LAI).

To test this hypothesis, conditioned media were collected from endothelial cell cultures grown in $100-\mathrm{mm}$ dishes. The HEC were washed to remove culture media and incubated in RPMI plus FCS with and without IL-1 for $4 \mathrm{~h}$, at which point the HEC were washed again. After incubation for an additional $5 \mathrm{~h}$ in fresh RPMI plus FCS, IL-1 CM and SHAM CM

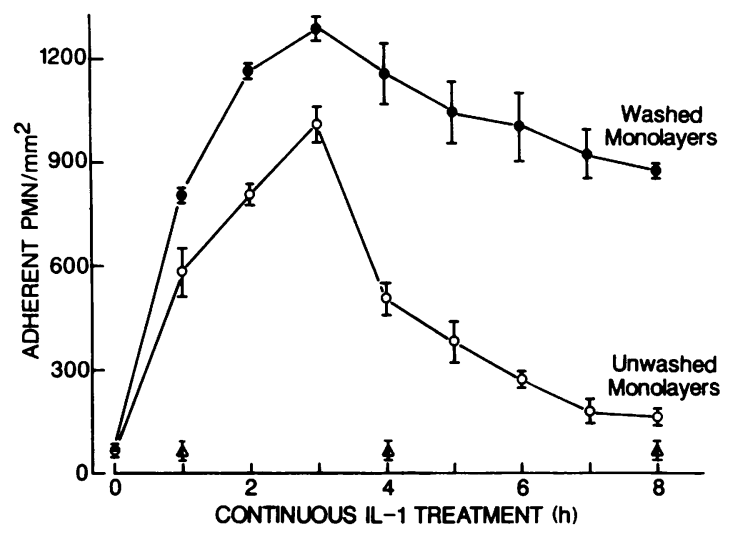

Figure 1. PMN adhesion to IL-1 treated endothelial monolayers. Confluent HEC monolayers, grown on Thermanox coverslips in Costar wells, were pretreated with hmIL-1 $(5 \mathrm{U} / \mathrm{ml})$ for the times indicated, and the number of adherent ${ }^{11}$ In-labeled PMN determined in a standard 10 min monolayer adhesion assay (see Methods). Closed circles (washed) indicate wells from which the conditioned medium was removed and the monolayers washed immediately before PMN addition. Open circles (unwashed) indicate wells in which PMN were added directly into the conditioned medium (equivalent volume of medium and number of PMN per well). PMN adhesion to untreated HEC in the presence (open triangles) or absence (closed triangles) of conditioned medium is indicated at 1,4 , and $8 \mathrm{~h}$.

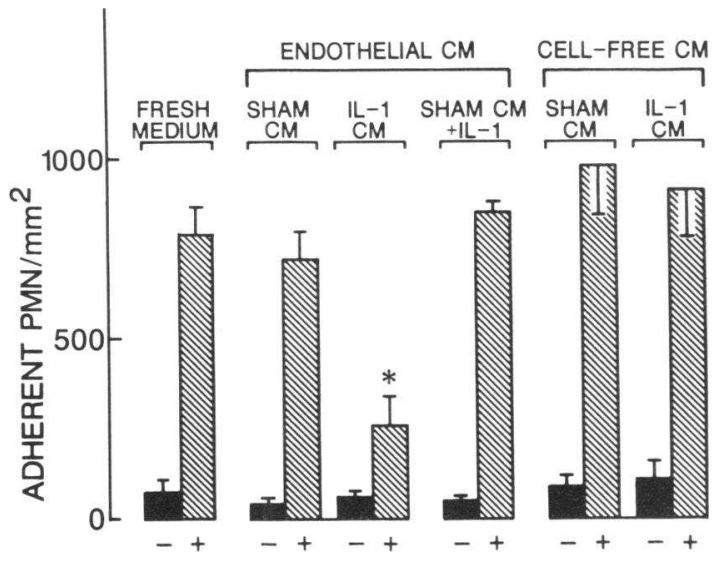

Figure 2. Effect of various conditioned media on PMN adhesion to stimulated and unstimulated endothelial cells. Conditioned media were collected as follows: (1) IL-1 CM and SHAM CM were collected from HEC monolayers pretreated with and without rIL-1 $\beta$ for $4 \mathrm{~h}$, washed, and incubated in RPMI + FCS for a subsequent $5 \mathrm{~h}$ (endothelial CM), or (2) RPMI + FCS was incubated with and without rIL-1 $\beta(5 \mathrm{U} / \mathrm{ml}, 9 \mathrm{~h})$ in gelatin-coated petri dishes without endothelial cells (cell-free CM). ${ }^{11}$ In-labeled PMN were diluted in unincubated RPMI + FCS (fresh medium), SHAM CM and IL-1 CM (2 $\times 10^{6} \mathrm{cell} / \mathrm{ml}$ ) from HEC monolayers (endothelial CM) or SHAM and IL-1 CM incubated in the absence of endothelial cells (cell-free $\mathrm{CM}$ ) before assay of LAI activity (see Methods). In addition, rIL- $\beta$ ( 5 $\mathrm{U} / \mathrm{ml}$ ) also was added directly to an aliquot of endothelial SHAM CM immediately before assay (SHAM CM + IL-1). In each case, PMN adhesion to both unactivated HEC monolayers ("-", solid bars) and activated HEC monolayers ("+", hatched bars) $(5 \mathrm{U} / \mathrm{ml}$ rIL- $\beta, 4 \mathrm{~h}$ ) was assessed. Values are expressed as mean \pm standard deviation for triplicate determinations in this representative experiment. Similar results were obtained in two additional experiments. $\left({ }^{*} P<0.001\right.$ IL-CM vs. SHAM CM).

were collected and assayed for inhibition of PMN adhesion to treated and untreated HEC monolayers. PMN adhesion to untreated HEC monolayers was unaltered by the presence of IL-1 CM as compared to SHAM CM (10 $44 \%$ inhibition, 10 experiments, $P>0.05$ ). In contrast, PMN adhesion to hyperadhesive HEC monolayers (pretreated with 2.5-5 U/ml rIL-1, $4 \mathrm{~h}$ ) was significantly inhibited in the presence of IL-1 CM (72 $\pm 6 \%$ inhibition, 10 experiments, $P<0.001$ ), as compared with SHAM CM. As illustrated in Fig. 2, when the extent of PMN adhesion to untreated or cytokine-treated HEC monolayers in the presence of SHAM CM was compared to fresh buffer, no significant difference was observed. Furthermore, SHAM CM, to which rIL- $1 \beta(5 \mathrm{U} / \mathrm{ml})$ was added just before assay, had no effect on PMN adhesion to either treated or untreated HEC monolayers. Incubation of $\mathrm{rIL}-1 \beta(5 \mathrm{U} / \mathrm{ml})$ containing medium in the absence of endothelial cells (Cellfree $\mathrm{CM}$ ) did not result in the generation of inhibitory activity. In addition to human monocyte-derived IL-1 and human recombinant IL- $1 \beta$, certain other agents including human recombinant IL- $1 \alpha$, human recombinant TNF and bacterial LPS, also induced the generation of LAI activity by HEC monolayers (Table I). Polymyxin B sulfate treatment signifcantly reduced the stimulatory effect of LPS but did not reduce the effect of rIL- $1 \beta$. In contrast, rIL-2, rIFN- $\gamma$, and GM-CSF did not stimulate LAI production.

Acetylsalicylic acid $(500 \mu \mathrm{M})$ treatment of the HEC did not alter LAI production, (90-97\% of LAI activity from untreated 
Table I. Effects of Cytokines and Bacterial Endotoxin on LAI Production by Cultured Human Endothelial Cells

\begin{tabular}{lc}
\hline \multicolumn{1}{c}{ Agent $^{*}$} & LAI activity \\
\hline & Percent inhibition of PMN adhesion \\
hm-IL-1 $(5 \mathrm{U} / \mathrm{ml})$ & $72 \pm 6(10)$ \\
rIL-1 $\alpha(10 \mathrm{U} / \mathrm{ml})$ & $58 \pm 7(4)$ \\
rIL-1 $\beta(2.5 \mathrm{U} / \mathrm{ml})$ & $69 \pm 10(10)$ \\
+ Polymyxin B $(100 \mu \mathrm{g} / \mathrm{ml})$ & $66 \pm 7(2)$ \\
+ Heat $\left(100^{\circ} \mathrm{C}, 15 \mathrm{~min}\right)$ & $7 \pm 13(2)$ \\
rTNF $(200 \mathrm{U} / \mathrm{ml})$ & $54 \pm 4(3)$ \\
LPS $(1 \mu \mathrm{g} / \mathrm{ml})$ & $39 \pm 8(5)$ \\
+ Polymyxin B $(100 \mu \mathrm{g} / \mathrm{ml})$ & $12 \pm 3(2)$ \\
+ Heat $\left(100^{\circ} \mathrm{C}, 15 \mathrm{~min}\right)$ & $33 \pm 5(2)$ \\
IFN- $\gamma(200 \mathrm{U} / \mathrm{ml})$ & $-1 \pm 9(5)$ \\
GM-CSF $(200 \mathrm{ng} / \mathrm{ml})$ & $-1 \pm 15(3)$ \\
IL-2 $(500 \mathrm{U} / \mathrm{ml})$ & $-9 \pm 9(3)$ \\
\end{tabular}

* Confluent monolayers were treated for $4 \mathrm{~h}$ in RPMI + FCS with the various agents indicated (at maximal concentrations for other known effects of the agent), washed, and incubated $5 \mathrm{~h}$ in RPMI + FCS. Conditioned media were collected and assayed for LAI activity (without dilution) in a standard monolayer cell adhesion assay against washed IL-1 treated ( 5 U rIL-1 $\beta, 4$ h) HEC monolayers. Data are presented as mean \pm SEM in $(n)$ separate experiments.

HEC, three experiments) under conditions that ablated constitutive and calcium ionophore stimulated $\mathrm{PGI}_{2}$ production (data not shown). Similar results were obtained with indomethacin pretreatment indicating that arachidonic acid metabolism via the cyclooxygenase pathway was not required for generation of LAI activity. However, treatment of HEC with actinomycin $\mathrm{D}(5 \mu \mathrm{g} / \mathrm{ml})$ for 30 min prior to stimulation with rIL-1 $\beta$ (2.5-5 U/ml, 4 h) essentially blocked subsequent LAI production (0-10\% of LAI activity from untreated HEC, 6 experiments). Comparable amounts of LAI activity were detected in IL-1 CM collected in protein-free RPMI medium ( $65 \pm 4 \%$ LAI activity, four experiments), in serum-free, TISsupplemented medium (58 $\pm 3 \%$ LAI activity, 10 experiments), and in BSA-supplemented medium ( $57 \pm 6 \%$ LAI activity, five experiments). The above observations suggest that de novo protein synthesis is required in the generation of LAI activity by the cytokine-stimulated endothelial cell and, further, that LAI activity does not result from the metabolism of some exogenously added medium component (e.g., a serum factor or IL-1).

Generation of LAI activity was found to be IL-1 concentration dependent with threshold at $0.1 \mathrm{U} / \mathrm{ml} \mathrm{rIL-1} \beta$ and maximal stimulation at $2.5-5 \mathrm{U} / \mathrm{ml}$ (Fig. 3). The appearance of LAI activity in the IL-1 CM was time dependent, as seen in fractionated hourly collections, with inhibitory activity consistently detectable at $1-2 \mathrm{~h}(30 \pm 6 \%$, five experiments), reaching a maximum at 5-6 h $(65 \pm 2 \%$, five experiments) following exposure to IL-1. LAI activity passed freely through an Amicon YM 30 (nominal molecular weight cutoff: 30,000 ) but was concentrated 10-20 times on an Amicon YM 5 (nominal molecular weight cutoff: 5,000). PMN adhesion was maximally blocked at a $5 \times$ concentration of IL-1 CM $(75 \pm 7 \%$, five experiments) with proportionately less LAI activity detectable at lower IL-1 CM concentrations (Fig. 4).

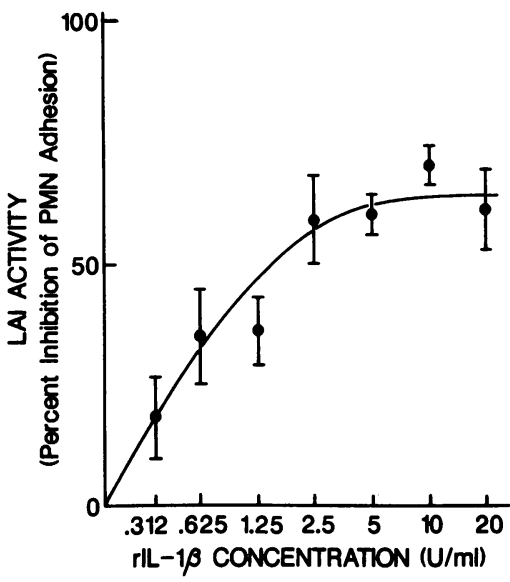

Figure 3. Concentration dependence of IL-1 stimulation of LAI generation by human endothelial cells. Confluent HEC monolayers were pretreated for $4 \mathrm{~h}$ with increasing concentrations of hmIL-1 or rIL- $1 \beta$, washed, and incubated an additional 5 $h$ in RPMI + FCS. IL-1 $\mathrm{CM}$ and SHAM CM then were collected and assayed for LAI activity in a standard monolayer adhesion assay.

Percent inhibition of PMN adhesion was calculated as described in Methods. Each point represents mean $( \pm$ SEM) from three separate experiments.

To determine whether LAI exerts its inhibitory effect on the leukocyte or the endothelial cell, each cell type was selectively pretreated. When activated HEC monolayers $(5 \mathrm{U} / \mathrm{ml}$ rIL-1 $\beta, 4 \mathrm{~h}$ ) were incubated for $30 \mathrm{~min}$ with IL- $1 \mathrm{CM}$, followed by exchange with fresh medium $(1.5 \mathrm{ml})$, no inhibition of PMN adhesion was observed (5 $\pm 8 \%$ inhibition, $P>0.05$, three experiments). In contrast, when PMN $\left(3 \times 10^{7}\right.$ cells in $1.5 \mathrm{ml}$ ) were pretreated with IL-1 CM for $30 \mathrm{~min}$, centrifuged $(100 \mathrm{~g}, 2 \mathrm{~min})$, resuspended in a comparable volume of fresh medium and added to an activated HEC monolayer, PMN adhesion was significantly inhibited $(25 \pm 3 \%$ inhibition, $P$ $<0.001$, three experiments). In addition, adhesion of unfixed PMN to fixed IL-1-stimulated HEC monolayers (2\% paraformaldehyde in PBS, $5 \mathrm{~min}, 22^{\circ} \mathrm{C}$, then stored overnight in PBS plus BSA at $4^{\circ} \mathrm{C}$ ) continued to be significantly inhibited by IL-1 CM (45 $\pm 9 \%$ inhibition, two experiments). In contrast, brief fixation of the PMN (2\% paraformaldehyde in PBS, 5 min, on ice) reduced the inhibitory effect of LAI by $>80 \%$. PMN fixation, per se, did not alter adhesion to untreated or IL-1-treated HEC monolayers (data not shown). These observations suggest that the inhibitory action of LAI is primarily directed at the leukocyte.

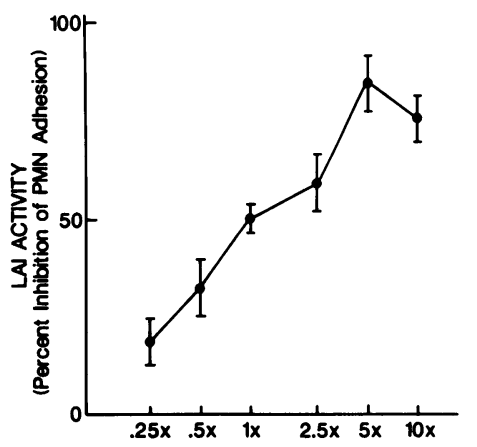

RELATIVE CONCENTRATION OF IL-1-TREATED ENDOTHEUAL CELL CONDTTONED MEDIUM
Figure 4. Concentration dependence of LAI-induced inhibition of PMN adhesion. IL-1 CM was collected in serum-free TIS supplemented medium from HEC monolayers stimulated with $5 \mathrm{U} / \mathrm{ml}$ rIL- $1 \beta$, as described in Methods, filtered through an Amicon YM 30 ultrafiltration membrane, and concentrated on an Ami-

con YM 5 membrane to a $20 \times$ concentrate (vol/vol). This IL-1 CM concentrate was then serially rediluted with RPMI + FCS for assay of LAI activity. Each point represents (mean \pm SEM) from five separate experiments. 
Conditioned medium from IL-1-stimulated HEC produced comparable inhibition of PMN adhesion to HEC target monolayers activated with TNF $(200 \mathrm{U} / \mathrm{ml}, 4 \mathrm{~h} ; 54 \pm 4 \%$, five experiments), LPS ( $1 \mu \mathrm{g} / \mathrm{ml}, 4 \mathrm{~h} ; 56 \pm 7 \%$, three experiments), or IL- $1 \beta(2.5 \mathrm{U} / \mathrm{ml}, 4 \mathrm{~h} ; 68 \pm 4$, five experiments). In contrast, IL-1 CM did not inhibit PMN adhesion to plastic surfaces coated with fresh human serum $(4 \pm 3 \%$ inhibition, four experiments), decomplemented human serum $(-10 \pm 4 \%$, three experiments) or zymosan activated human serum $(-8 \pm 10 \%$, three experiments). These results, taken together with the lack of effect on PMN adhesion to unactivated endothelial cells, suggest that LAI may act to preferentially inhibit leukocyte interaction with the "hyperadhesive" endothelial cell surface.

As illustrated in Fig. 5, LAI activity appears to differentially affect the adhesion of certain blood leukocytes to cytokine-activated and unactivated endothelium. IL-1 CM consistently produced a marked inhibition of PMN adhesion to activated HEC monolayers $(76 \pm 4 \%$ inhibition of cytokinestimulated adhesion, $P<0.001$, five experiments), but had no effect on PMN adhesion to unactivated monolayers. Similarly, monocyte adhesion to activated HEC monolayers was significantly inhibited $(55 \pm 12 \%$ inhibition of cytokine-stimulated adhesion, $P<0.01$, five experiments), while no effect on the relatively extensive adhesion to unactivated monolayers was observed. In contrast, IL-1 CM did not significantly alter the adhesion of peripheral blood lymphocytes $(-4 \pm 6 \%$ inhibition, $P>0.1$, three experiments), HL-60 cells $(2 \pm 6 \%, P>0.1$, four experiments), or U937 ( $1 \pm 9 \%, P>0.1$, four experiments) to either IL-1-activated or unactivated HEC monolayers.

Vital microscopy of PMN adhesion to activated HEC monolayers in the presence and absence of LAI revealed striking differences. In SHAM CM, large numbers of adherent PMN appeared well spread on the monolayer surface (Fig. 6 A). In contrast, in IL-1 CM, the extent of PMN adhesion was markedly reduced, consistent with the quantitative monolayer

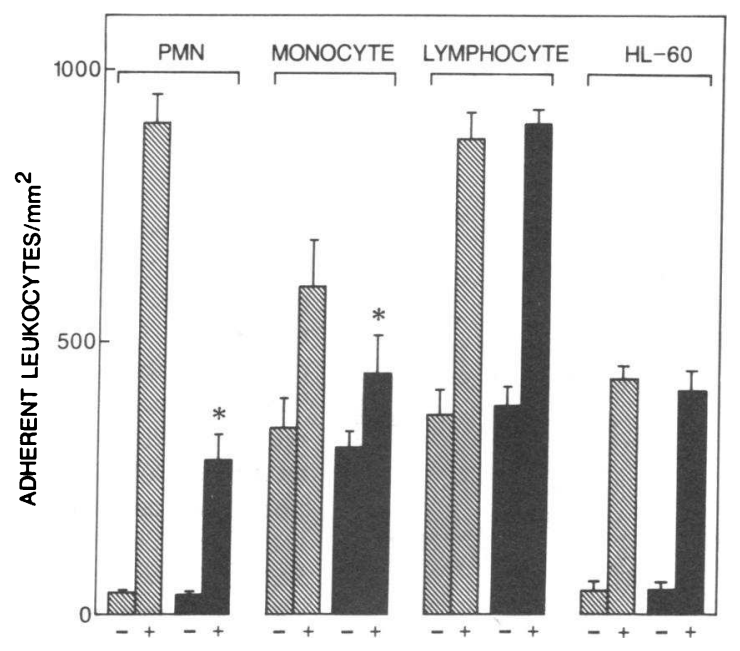

Figure 5. Effect of LAI on adhesion of different types of leukocytes to untreated and IL-1 treated endothelial cell monolayers. Isolated radiolabeled PMN, monocytes, lymphocytes, or HL-60 cells were resuspended in SHAM CM (striped bars) or IL-1 CM (solid bars) and adhesion to untreated $(-)$ or IL-1 treated $(+)(2.5 \mathrm{U} / \mathrm{ml} \mathrm{rIL-1 \beta ,4 \textrm {h } )}$ HEC was assessed in a 10-min assay. Values are expressed as mean $\pm \operatorname{SEM}\left({ }^{*} P<0.01 \mathrm{IL}-1 \mathrm{CM}\right.$ vs. SHAM CM) in three to five separate experiments.
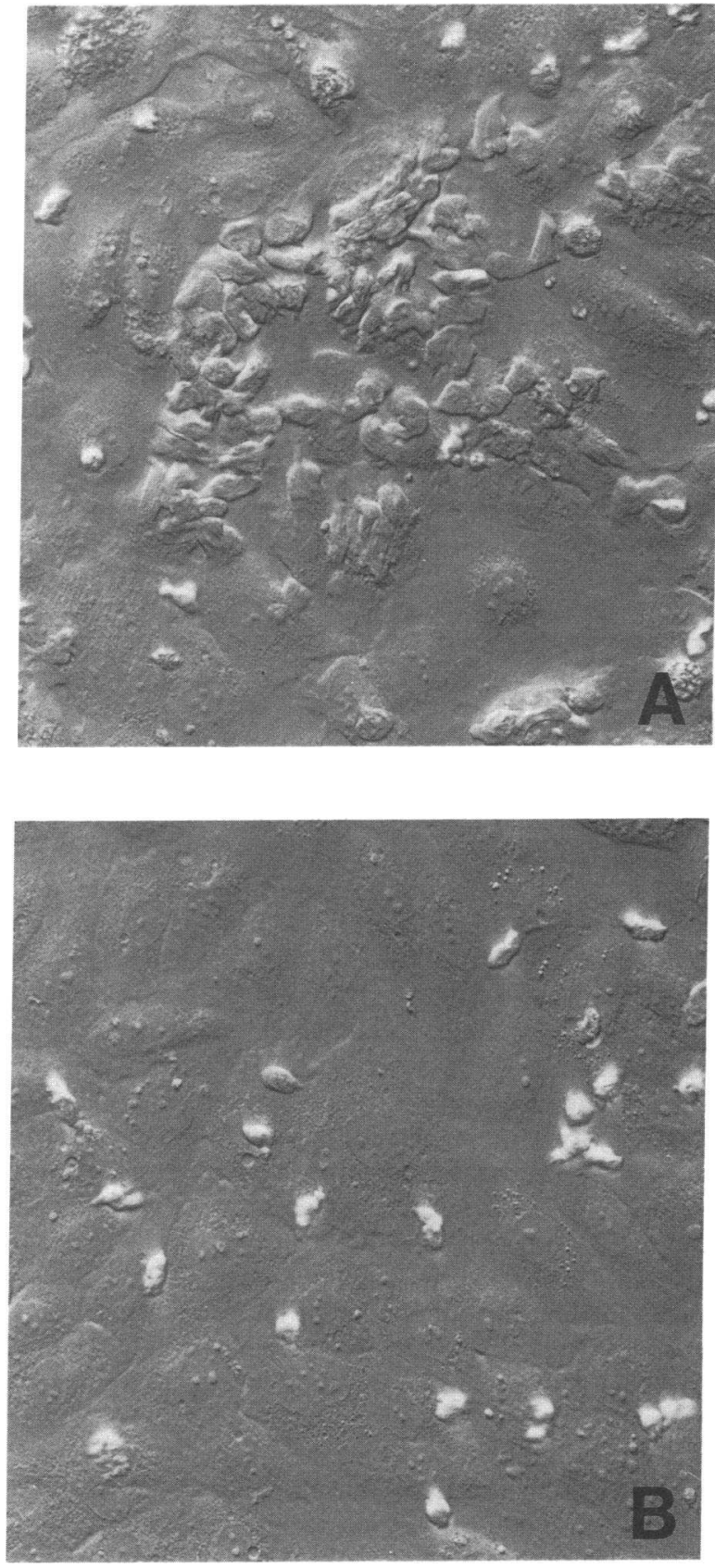

Figure 6. Hoffman differential-interference contrast microscopy of PMN adhesion to IL-1 treated HEC monolayers. Isolated PMN were resuspended in SHAM CM $(A)$ or IL-1 CM $(B)$ and added to IL-1 stimulated HEC ( $2.5 \mathrm{U} / \mathrm{ml} \mathrm{rIL-1 \beta} 4 \mathrm{~h})$ for $10 \mathrm{~min}$, and the monolayers washed to remove nonadherent PMN. Note that in B the adherent PMN are reduced in number and appear less well spread on the surface of the HEC monolayer. (Original magnification, 400).

adhesion assay data. Interestingly, although individual PMN had undergone shape change with pseudopod extension, they did not appear spread on the monolayer surface in the presence of IL-1 CM (Fig. 6 B).

To determine whether LAI was producing a global inhibition of leukocyte function, we examined stimulus-response coupling and superoxide production in response to soluble stimuli. The addition of IL-1 CM or SHAM CM did not alter resting membrane potential or inhibit membrane depolariza- 

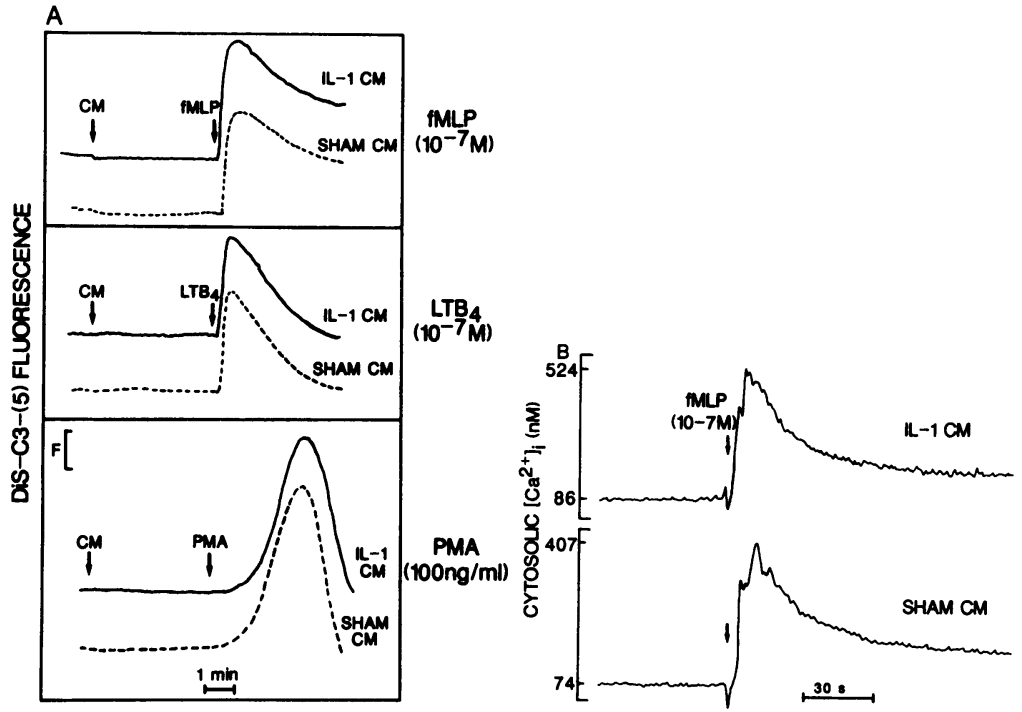

Figure 7. Agonist-induced membrane depolarization and transient $\mathrm{Ca}^{2+}$ rise in PMN. (A) PMN $\left(2 \times 10^{6} / \mathrm{ml}\right)$ were resuspended in $1.9 \mathrm{ml} \mathrm{HBSS}$ with $\mathrm{Ca}^{2+}$ and $\mathrm{Mg}^{2+}(2$ $\mathrm{mM})$ and equilibrated with $\operatorname{diSC}_{3}-(5)(1.5 \mu \mathrm{M}$ final concentration) at $37^{\circ} \mathrm{C}$ in a SPEX fluorimeter. $100-\mu l$ aliquot of a $20 \times$ concentrated SHAM CM (dotted line) or IL-1 CM (solid line) was added. After $5 \mathrm{~min}, 10^{-7} \mathrm{M}$ FMLP (top panel), $10^{-7} \mathrm{M} \mathrm{LTB}_{4}$ (middle panel), or 100 $\mathrm{ng} / \mathrm{ml}$ PMA (bottom panel) was added, and the increase in fluorescence recorded. $\mathrm{F}=10 \%$ full scale. $(B)$ Fura-2 loaded PMN $\left(1 \times 10^{6} / \mathrm{ml}\right)$ were suspended in $1.9 \mathrm{ml}$

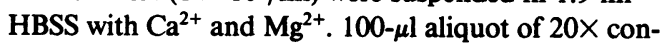
centrated IL-1 CM (top) or SHAM CM (bottom) was added. After $5 \mathrm{~min}, 10^{-7} \mathrm{M}$ FMLP was added and the change in fluorescence emission (excitation 340 and 380) was recorded at $505 \mathrm{~nm}$. Cytosolic free calcium concentrations ( $y$ axis) were calculated from the ratio of emitted fluorescence signals (14). tion induced by $10^{-7} \mathrm{M}$ FMLP, $10^{-7} \mathrm{M} \mathrm{LTB}_{4}$, or $100 \mathrm{ng} / \mathrm{ml}$ PMA (Fig. $7 A$ ). Similarly, neither IL-1 CM nor SHAM CM altered FMLP-induced rises in cytosolic calcium levels (Fig. 7 $B$ ). Superoxide production in response to $10^{-7} \mathrm{M}$ FMLP or $100 \mathrm{ng} / \mathrm{ml}$ PMA also was not inhibited by LAI (data not shown). Based on these results, LAI does not appear to interfere with leukocyte activation by soluble inflammatory stimuli.

To facilitate preliminary biochemical characterization, LAI was collected from IL-1 activated HEC monolayers in serum-free, transferrin/insulin/selenium-supplemented medium. LAI activity in these preparations was found to be stable to a variety of treatments, including boiling for $20 \mathrm{~min}$, acidification (pH 2 or 4 ) for $18 \mathrm{~h}$, freezing $\left(-80^{\circ} \mathrm{C}\right.$, up to $3 \mathrm{mo}$ ) and storage at $4^{\circ} \mathrm{C}$ for up to $14 \mathrm{~d}$ without the addition of protease inhibitors. LAI activity was non-sedimentable $(250,000 \mathrm{~g}, 45$ min) suggesting that it is soluble rather than associated with a membrane fragment. LAI activity was precipitated by ammonium sulfate at $60-80 \%$ saturation, and full activity was recovered in this fraction. LAI activity was not adsorbed by gelatinagarose, concanavalin A-agarose, or heparin-sepharose. Treatment of IL-1 CM, which had been filtered through a 30,000 molecular weight cutoff membrane, with trypsin $(1,000 \mathrm{U} / \mathrm{ml}$, pH $\left.7,37^{\circ} \mathrm{C}, 18 \mathrm{~h}\right)$, thrombin $\left(2 \mathrm{U} / \mathrm{ml}, 37^{\circ} \mathrm{C}, 2 \mathrm{~h}\right)$, or heparinase $\left(15 \mathrm{U} / \mathrm{ml}, 30^{\circ} \mathrm{C}, 2 \mathrm{~h}\right)$, did not affect LAI activity, whereas treatment with pepsin-linked agarose $(4,500 \mathrm{U} / \mathrm{ml}, \mathrm{pH} 4,18 \mathrm{~h}$, $\left.37^{\circ} \mathrm{C}\right)$ significantly reduced LAI activity $(13 \pm 7 \%$ in pepsintreated samples vs. $62 \pm 8 \%$ in acid-treated control samples, two experiments). These results suggest that the biological activity of LAI depends on a protein component.

Samples of ultrafiltered, dialyzed and lyophilized IL-1 CM were fractionated on a Waters Protein-Pak 125 gel filtration column by high pressure liquid chromatography as described in Methods. Fractions $(0.8 \mathrm{ml})$ were dialyzed against PBS ( $\mathrm{pH}$ 7.4), diluted 1:10 in RPMI plus FCS and assayed for LAI activity. In this chromatography system, the peak of LAI activity (fraction 12) was separated from the major protein peak (fraction 9) (Fig. 8). LAI activity in the peak fraction was present at an effective concentration of $80 \times$, based on serial dilution to the endpoint of $50 \%$ inhibition of PMN adhesion. The total LAI activity recovered, as estimated from assay of serial dilutions of each active fraction, was $>90 \%$. LAI activity in the peak fraction was stable to boiling, acidification, and was completely destroyed by treatment with pepsin $(-8 \pm 6 \%$ LAI activity in pepsin-treated samples vs. $62 \pm 10 \%$ in acidtreated control samples), thus confirming its protein nature.

\section{Discussion}

Adhesion of leukocytes to the endothelial lining of blood vessels is an essential event in the inflammatory process. In addition to the proadhesive cell surface changes observed in the "activated" endothelial cell (1-9), cytokine- and bacterial endotoxin-stimulated endothelial cultures also generate an antiadhesive activity, specifically, an inhibitor of leukocyte adhesion (LAI). LAI is an inducible, soluble product released by the activated endothelial cell, the biological activity of which is protein dependent. No detectable LAI activity is found in conditioned medium from untreated human endothelial cultures. Cytokine treatment of endothelial cultures has been reported to result in altered production of several biologically

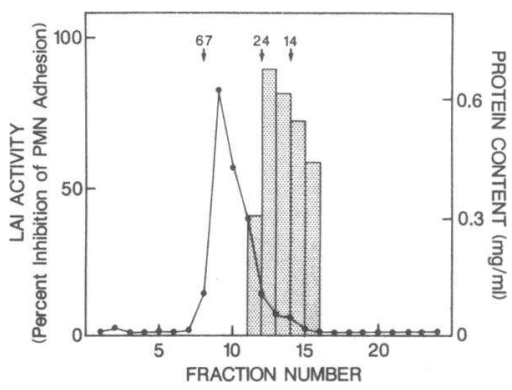

Figure 8. Fractionation of IL-1 CM by high pressure liquid chromatography. IL-1 CM was collected in serum-free, TIS-supplemented medium, filtered through an Amicon YM 30 membrane, concentrated on a YM 5 membrane, washed to remove salts, and lyophi-

lized. Aliquots were resuspended in $0.2 \mathrm{M}$ acetic acid, $0.1 \mathrm{M}$ triethylamine ( $\mathrm{pH}$ 3.9), and applied to a Waters Protein-PAK 125 gel filtration column. Fractions were collected at a flow rate of $1.8 \mathrm{ml} /$ min, dialyzed against PBS and diluted 1:10 with RPMI + FCS for assay of LAI activity (stippled bars). Protein content was determined in undiluted fractions in PBS (closed circles). Similar results were obtained in three additional experiments. Arrows indicated molecular weight markers of bovine serum albumin $(67,000 \mathrm{D})$, soybean trypsin inhibitor $(24,000)$, and egg lysozyme $(14,000)$. 
active substances, including prostacyclin $(16,17)$. However, its protein nature, thermo- and acid stability and production in the presence of aspirin or indomethacin (at concentrations that ablate cyclooxygenase activity in cultured endothelial cells [18]), distinguish LAI activity from various endogenous phospholipid metabolites that have been shown to influence leukocyte function (19-21).

LAI significantly reduces the extent of leukocyte adhesion to activated endothelial cells without producing a global inhibition of leukocyte function. This selective action is in contrast to that of certain other known inhibitors of leukocyte function produced by endothelial cells. For example, adenosine, which is released by cultured endothelial cells under basal conditions (22) as well as in response to oxidant stress (23), inhibits both FMLP-stimulated PMN adhesion to unactivated endothelial cells $(24)$ and PMN superoxide production $(25,26)$. Other chemically undefined endothelial-derived substances also appear to inhibit PMN adhesion to unstimulated endothelial monolayers and inert (plastic) surfaces $(27,28)$. Interestingly, purified human monocyte-derived IL-1 has also been reported to inhibit PMN adhesion to inert surfaces (29). However, in our assay system, the direct addition of rIL- $1 \beta$ was found to be without effect on PMN adhesion to unactivated or cytokineactivated HEC monolayers.

The leukocyte type-selective effect of LAI, that is, the inhibition of PMN and monocyte adhesion, but not lymphocyte, HL-60 or U937 adhesion, suggests that the action of LAI may be directed at functions or surface structures that vary with leukocyte type and/or are deficient in the less differentiated cell lines. Adhesive interactions of certain leukocytes with cultured endothelium, under both activated and basal conditions, have been demonstrated to involve, in part, the leukocyte surface differentiation antigen complex CD11/18 (LFA-1, Mac-1, p150,95) $(6-8,30,31)$. It remains to be determined if LAI interacts with components of the CD11/18 complex to produce its inhibitory effect. Interestingly, concentrated LAI (up to five times) did not inhibit either the adhesion of PMN stimulated with FMLP, LTB $_{4}$ or PMA to unactivated endothelial monolayers (Wheeler, M. E., unpublished observations), or the adhesion of unstimulated PMN to serum-coated inert surfaces. In contrast, monoclonal antibodies to CD11/18 complex produce a significant inhibition of agonist-induced PMN adhesion to unactivated endothelial monolayers as well as to inert surfaces (32). These results suggest that LAI may interfere with PMN adhesion mechanisms uniquely involved in the recognition of the activated endothelial cell surface.

Studies from our laboratory have implicated the inducible expression of endothelial-leukocyte adhesion molecules (ELAMs) in the cytokine-stimulated "hyperadhesive" surface change $(1-3,9,33)$. Specifically, ELAM-1 has been shown to be involved in PMN and HL-60 adhesion to IL-1 treated endothelium and monoclonal antibodies against ELAM-1 (H4/18 and $\mathrm{H}_{18 / 7)}$ block this adhesion (9). These observations raise the question of a potential relationship between ELAM- 1 and LAI. For example, it is possible that LAI may be a "shed" portion of the ELAM-1 molecule that can compete with endothelial cell surface-expressed ELAM-1 for its putative PMN receptor. However, under conditions where monoclonal antibodies $\mathrm{H} 4 / 18$ and $\mathrm{H} 18 / 7$ immunoprecipitate ELAM-1 from detergent cell extracts $(9,33)$, LAI activity was not removed from IL-1 CM. In addition, when LAI and H18/7 were both present in the adhesion assay, PMN adhesion to activated en- dothelial cells was inhibited in an additive fashion, thus suggesting that LAI does not act by blocking the putative PMN receptor for ELAM-1 (Wheeler, M. E., unpublished observations).

In summary, we have demonstrated that cultured human endothelial cells, stimulated by cytokines or endotoxin, not only express surface molecules that enhance leukocyte adhesion, but also generate a soluble, protein-containing inhibitor that selectively inhibits leukocyte attachment to the hyperadhesive endothelial surface. In combination, these active endothelial pro- and antiadhesive alterations may be part of a physiologic mechanism that regulates local leukocyte-vessel wall adhesive interactions at sites of inflammation in vivo. Further characterization of LAI may provide insight into "natural" antiinflammatory mechanisms.

\section{Acknowledgments}

We gratefully acknowledge the expert assistance of Ms. Anne Brock in leukocyte adhesion experiments, Ms. Kay Case and Ms. Vannessa Davis in cell culture, and Ms. Cathy Curtis in preparation of this manuscript. We also wish to thank Dr. Charles Serhan and Ms. Eileen Reardon for valuable assistance with the HPLC fractionation and Dr. Roy Lobb and Dr. Jordan Pober for helpful discussions.

This research was supported by National Institutes of Health grants PO1-HL-36028, T32-HL07066, and F32-HL07324 (M. E. Wheeler).

\section{References}

1. Bevilacqua, M. P., J. S. Pober, M. E. Wheeler, R. S. Cotran, and M. A. Gimbrone, Jr. 1985. Interleukin-1 acts on cultured human vascular endothelium to increase adhesion of polymorphonuclear leukocytes, monocytes, and related cell lines. J. Clin. Invest. 76:2003-2011.

2. Bevilacqua, M. P., J. S. Pober, M. E. Wheeler, R. S. Cotran, and M. A. Gimbrone, Jr. 1985. Interleukin-1 activation of vascular endothelium. Effects oh procoagulant activity and leukocyte adhesion. Am. J. Pathol. 121:393-403.

3. Bevilacqua, M. P., M. E. Wheeler, J. S. Pober, W. Fiers, D. L. Mendrick, R. S. Cotran, and M. A. Gimbrone, Jr. 1986. Endothelialdependent mechanisms of leukocyte adhesion: regulation by interleukin 1 and tumor necrosis factor. In Leukocyte Emigration and Its Sequelae. H. E. Movat, editor. S. Karger, AG, Basel/New York. 79-93.

4. Dunn, C. J., and W. E. Fleming. 1985. The role of interleukin-1 in the inflammatory response with particular reference to endothelial cell-leukocyte adhesion. In The Physiologic, Metabolic, and Immunologic Actions of Interleukin-1. M. J. Kluger, J. J. Oppenheim, and M. C. Powanda, editors. Alan R. Liss, Inc., New York. 45-54.

5. Schleimer, R. P., and B. K. Rutledge. 1986. Cultured human vascular endothelial cells acquire adhesiveness for neutrophils after stimulation with interleukin 1, endotoxin, and tumor-promoting phorbol diesters. J. Immunol. 136:649-654.

6. Gamble, J. R., J. M. Harlan, S. J. Klebanoff, A. F. Lopez, and M. A. Vadas. 1985. Stimulation of the adherence of neutrophils to umbilical vein endothelium by human recombinant tumor necrosis factor. Proc. Natl. Acad. Sci. USA. 82:8667-8671.

7. Pohlman, T. H., K. A. Stanness, P. G. Beatty, H. D. Ochs, and J. M. Harlan. 1986. An endothelial cell surface factor(s) induced in vitro by lipopolysaccharide, interleukin 1 , and tumor necrosis factor increases neutrophil adherence by a CDw18-dependent mechanism. $J$. Immunol. 136:4548-4553.

8. Cavender, D., D. Haskard, C-L. Yu, T. Iguchi, P. Miossec, N. Oppenheimer-Marks, and M. Ziff. 1987. Pathways to chronic inflammation in rheumatoid synovitis. Fed. Proc. 46:113-117.

9. Bevilacqua, M. P., J. S. Pober, D. L. Mendrick, R. S. Cotran, and M. A. Gimbrone, Jr. 1987. Identification of an inducible endothelial- 
leukocyte adhesion molecule. Proc. Natl. Acad. Sci. USA. 84:92389242.

10. Recalde, H. 1984. A simple method of obtaining monocytes in suspension. J. Immunol. Methods. 69:71-77.

11. Charo, I. F., C. Yuen, and I. M. Goldstein. 1985. Adherence of human polymorphonuclear leukocytes to endothelial monolayers: effects of temperature, divalent cations, and chemotactic factors on the strength of adherence measusured with a new centrifugation assay. Blood. 65:473-479.

12. Whitin, J. C., C. E. Chapman, E. R. Simons, M. E. Chovanice, and H. J. Cohen. 1980. Correlation between membrane potential changes and superoxide production in human granulocytes stimulated by phorbol myristate acetate: evidence for defective activation in chronic granulomatous disease. J. Biol. Chem. 255:1874-1878.

13. Luscinskas, F. W., D. E. Mark, B. Brunkhorst, F. J. Lionetti, E. J. Cragoe, Jr., and E. R. Simons. 1988. The role of transmembrane cationic gradients in immune complex stimulation of human polymorphonuclear leukocytes. J. Cell. Physiol. 134:211-219.

14. Grynkiewicz, G., M. Poenie, and R. Y. Tsien. 1985. A new generation of $\mathrm{Ca}^{2+}$ indicators with greatly improved fluorescence properties. J. Biol. Chem. 260:3440-3450.

15. Cohen, H. J., and M. E. Chavaniec. 1978. Superoxide generation by digitonin-stimulated guinea pig granulocytes. A basis for a continuous assay monitoring superoxide production and for the study of the activation of the generating system. J. Clin. Invest. 61:10811088.

16. Dejana, E., F. Breviario, G. Balconi, V. Rossi, G. Remuzzi, G. de Gaetano, and A. Mantovani. 1984. Stimulation of prostacyclin synthesis in vascular cells by mononuclear cell products. Blood. 64:1280-1283.

17. Albrightson, C. R., N. L. Baenziger, and P. Needleman. 1985. Exaggerated human vascular cell prostaglandin biosynthesis mediated by monocytes: role of monokines and interleukin 1. J. Immunol. 135:1872-1877.

18. Buchanan, M. R., M. J. Vazquez, and M. A. Gimbrone, Jr. 1983. Arachidonic acid metabolism and the adhesion of human polymorphonuclear leukocytes to cultured vascular endothelial cells. Blood. 62:889-895.

19. Zimmerman, G. A., G. A. Wiseman, and H. R. Hill. 1985. Human endothelial cells modulate granulocyte adherence and chemotaxis. J. Immunol. 134:1866-1874.

20. Zimmerman, G. A., T. M. McIntyre, and S. M. Prescott. 1987. Naturally occurring lipids influence the interaction of human endothelial cells and neutrophils. In Leukocyte Emigration and Its Sequelae. H. E. Movat, editor. S. Karger, AG, Basel/New York. 105-118.

21. Buchanan, M. R., T. A. Haas, M. Lagarde, and M. Guichar- dant. 1985. B-Hydroxyoctadecadienoic acid is the vessel wall chemorepellant factor, LOX. J. Biol. Chem. 260:16056-16059.

22. Pearson, J. D., and J. L. Gordon. 1979. Vascular endothelial and smooth muscle cells in culture selectively release adenine nucleotides. Nature (Lond.). 281:384-386.

23. Ager, A., and J. L. Gordon. 1984. Differential effects of hydrogen peroxide on indices of endothelial cell function. J. Exp. Med. 159:592-603.

24. Cronstein, B. N., R. I. Levin, J. Belanoff, G. Weissman, and R. Hirschhorn. 1986. Adenosine: an endogenous inhibitor of neutrophilmediated injury to endothelial cells. J. Clin. Invest. 78:760-770.

25. Cronstein, B. N., S. B. Kramer, G. Weissman, and R. Hirschhorn. 1983. Adenosine: a physiological modulator of superoxide anion generation by human neutrophils. J. Exp. Med. 158:1160-1177.

26. Roberts, P. A., A. C. Newby, M. B. Hallett, and A. K. Campbell. 1985. Inhibition of adenosine of reactive oxygen metabolite production by human polymorphonuclear leukocytes. Biochem. J. 227:669-674.

27. Kerr, C., B. Rogers, and R. L. Hoover. 1986. The effect of leukocyte:endothelial cell interactions on subsequent adhesion of leukocytes to endothelial cells. J. Cell Biol. 103:971 a. (Abstr.)

28. Hoover, R. L., J. M. Robinson, and M. J. Karnovsky. 1982. Superoxide production by polymorphonuclear leukocytes is inhibited by contact with endothelial cells. J. Cell Biol. 95:10a. (Abstr.)

29. Appelboom, T. M. Pierart, G. Ameryckx, and N. Mairesse. 1987. Partial characterization of the soluble mediator of leukocyte adherence inhibition. J. Rheumatol. 14:420-425.

30. Haskard, D., D. Cavender, P. Beatty, T. Springer, and M. Ziff. 1986. T lymphocyte adhesion to endothelial cells: Mechanisms demonstrated by anti-LFA-1 monoclonal antibodies. J. Immunol. 137:2901-2906.

31. Cavender, D., Y. Saegusa, and M. Ziff. 1987. Stimulation of endothelial cell binding of lymphocytes by tumor necrosis factor. $J$. Immunol. 139:1855-1860.

32. Wallis, W. J., D. D. Hickstein, B. R. Schwartz, C. H. June, H. D. Ochs, P. G. Beatty, S. J. Klebanoff, and J. M. Harlan. 1986. Monoclonal antibody-defined functional epitopes on the adhesionpromoting glycoprotein complex (CDw18) of human neutrophils. Blood. 67:1007-1013.

33. Pober, J. S., M. P. Bevilacqua, D. L. Mendrick, L. A. Lapierre, W. Fiers, and M. A. Gimbrone, Jr. 1986. Two distinct monokines, interleukin 1 and tumor necrosis factor, each independently induce biosynthesis and transient expression of the same antigen on the surface of cultured human vascular endothelial cells. J. Immunol. 136:1680-1687. 